\title{
A LÓGICA ECONÔMICO-PUNITIVA EM MUTAÇÃO: DO SUJEITO COMO MÃO- DE-OBRA AO NÃO-SUJEITO COMO MATÉRIA-PRIMA
}

\author{
THE ECONOMIC-PUNITIVE LOGIC IN MUTATION: FROM THE SUBJECT AS A \\ WORKMAN TO THE NON-SUBJECT AS RAW MATERIAL
}

Debora Regina Pastana

\begin{abstract}
Doutora em Sociologia pela Faculdade de Ciências e Letras - FCL da Universidade Estadual Paulista - UNESP. Atualmente é professora adjunta do Instituto de Ciências Sociais (INCIS) da Universidade Federal de Uberlândia (UFU) e professora permanente do Programa de Pós Graduação em Direito Público da UFU. Também é coordenadora do grupo de estudos sobre violência e controle social (GEVICO).

E-mail: deborapastana@ufu.br

Danler Garcia Silva

Graduando em Direito pela Universidade Federal de Uberlândia (UFU). Bolsista do Conselho Nacional de Desenvolvimento Científico e Tecnológico (CNPq) de iniciação científica. E-mail: danler.gs@gmail.com
\end{abstract}

Recebido em:24/11/2016

Aprovado em: 22/08/2017

Doi: $10.5585 /$ rdb.v18i7.545

RESUMO: Este trabalho possui como escopo investigar a correlação existente no binômio controle penal/economia quando comparamos os arquétipos moderno e contemporâneo. Possuindo como alicerce os estudos de Rusche e Kirchheimer, Melossi, Pavarini, Wacquant, Giorgi entre outros, assevera-se a pertinência da temática para o debate crítico concernente aos sistemas penais e seus mecanismos de punição atrelados à estruturas político-econômicas. No mesmo sentido, e em real destaque, observamos a alocação e significação dos sujeitos inseridos nestas ordens, transmutando-se de um sujeito como mão-de-obra em um período moderno, à um não sujeito como matéria-prima em um momento contemporâneo. Esta abordagem se justifica na medida em que transformações econômicas significativas redefiniram amplamente os sentidos do encarceramento contemporâneo, colocando em xeque o paradigma moderno de punição.

Palavras-chave: Punição; Economia; Privatização Prisional.

ABSTRACT: This work has as its scope to investigate the correlation existing in the binomial
criminal control/economy when compared to modern and contemporary archetypes. Possessing
as foundation studies of Rusche and Kirchheimer, Melossi and Pavarini, Wacquant, Giorgi
among others, asserts the relevance of the theme for the critical debate concerning the penal
systems and mechanisms of punishment linked to the political and economic structures.
Similarly, and in real highlight, we observe the allocation and the significance of subjects
inserted in these orders, transmuting from a subject as hand labor in a modern period, to a non-
subject as raw material in a contemporary moment. This approach is justified insofar as 
significant economic transformations have broadly redefined the meanings of contemporary incarceration, challenging the modern paradigm of punishment.

Key-words: Punishment; Economy; Prison Privatization

SUMÁRIO: Introdução; 1. Punição e economia na modernidade; 2. Punição e economia na contemporaneidade; Conclusão; Referências bibliográficas.

\section{INTRODUÇÃO}

A correspondência entre crime, controle penal e mercado, mais pontualmente entre punição e economia, é examinada desde a modernidade à contemporaneidade sob prismas piamente distintos e, independentemente do viés teórico-metodológico adotado, esta emblemática correlação mostrou-se significativa em diversos estudos e períodos.

Em Criminologia destaca-se uma contundente e plural vertente marxista, cujas categorias analíticas explicitam com veemência o estudo dos sistemas punitivos atrelando-os às estruturas econômicas. Como assevera Juarez Cirino dos Santos (2006, p. 5), estas categorias estão "fundadas no conceito de modo de produção da vida social, que exprime a integração das forças produtivas materiais em determinadas relações de produção históricas, nas quais se manifesta a luta de classes na formação social capitalista".

De fato, o olhar materialista da tradição marxista de pensamento não se reduz às meras reflexões provenientes da razão, ao contrário desconstrói as verdades jurídico-penais do Iluminismo. Ao negar a assertiva de que a pena é uma consequência do delito, bem como que os sistemas penais e punitivos possuem um cariz evolutivo; já estabelecem uma forte crítica ao pensamento criminológico positivista. Contudo, ao relacionarem as instituições de controle modernas à estrutura político-econômica do momento, aprofundam a reflexão oferecendo uma perspectiva que definitivamente inaugura um olhar não etiológico sobre o desvio.

Assim, influenciada pelo pensamento marxista, a criminologia crítica se manifesta como uma construção criminológica atrelada e conduzida pelo método materialista, uma vez que refuta as conjecturas que asseguram que o fenômeno criminal é proveniente de fenômenos causais e que os reduz à uma investigação microssociológica da questão. Por consequência, a criminologia crítica reorienta seu objeto de pesquisa face aos métodos e instituições de poder criminalizantes, à práxis das organizações do sistema penal, bem como à associação entre estrutura políticoeconômica e controle social (CARVALHO, 2013, p. 284).

Possuindo como pilar teórico-metodológico a criminologia crítica, especialmente suas reflexões analíticas que investigam a correlação entre as estruturas macrossociais e o sistema penal, este trabalho analisará, sob um prisma crítico, a associação entre a lógica econômica e a lógica punitiva desde a modernidade à contemporaneidade, cuja problemática atinge seu ápice por meio das privatizações do sistema prisional e parcerias público-privadas. Trata-se, portanto, de análise crítica, cuja metodologia dialética procura considerar os fenômenos históricos e suas representações sociais em constante transformação. Nesse sentido, dialeticamente aspira-se compreender e desnudar as mutações dos sujeitos alocados nessa esfera econômico-punitiva, que perpassa de um sujeito como mão-de-obra, na modernidade, a um sujeito como matéria-prima, na contemporaneidade.

\section{PUNIÇÃO E ECONOMIA NA MODERNIDADE}

Precursores nessa reflexão, Georg Rusche e Otto Kirchheimer reclinam-se e refutam as teorias e raciocínios de matriz liberal que asseveram que o sistema prisional, enquanto mecanismo punitivo, é proveniente da humanização, progresso e racionalidade dos artifícios 
penais frente às táticas de punição brutais do período pré-moderno. Para tanto, os autores certificam-se de que cada arquétipo econômico detém uma lógica e técnicas de punição específicas, e que, por consequência, cada sistema punitivo depende, sobremaneira, da manutenção de cada estágio econômico. Não sem razão, os autores atestam que:

Todo sistema de produção tende a descobrir formas punitivas que correspondem às suas relações de produção. É, pois, necessário pesquisar a origem e a força dos sistemas penais, o uso e a rejeição de certas punições e a intensidade das práticas penais, uma vez que elas são determinadas por forças sociais, sobretudo pelas forças econômicas e, consequentemente, fiscais. [...] Quando nos voltamos para os fatores condicionantes positivos, podemos ver que a simples constatação de que formas específicas de punição correspondem a um dado estágio de desenvolvimento econômico é uma obviedade. [...] De outro lado, o desparecimento de um dado sistema de produção faz com que a pena correspondente fique inaplicável. Somente um desenvolvimento específico das forças produtivas permite a introdução ou a rejeição de penalidades correspondentes. Porém, antes que métodos potenciais sejam introduzidos, a sociedade precisa estar em condições de incorporá-los como parte de todo o sistema social e econômico (RUSCHE; KIRCHHEIMER, 2004, p. 20).

Seguindo essas reflexões é possível perceber que é a modernidade o momento cuja racionalidade penal aparece como medida de controle social das massas de modo a discipliná-la. Dito de outra forma, nesse momento histórico a punição passa a combater, precipuamente, as massas depauperadas que migravam do campo rumo às insurgentes cidades. Trabalhadores expropriados do campo, que nas cidades transformavam-se em vagabundos, mendigos e bandidos, passam a ser alvos de uma política punitiva encarceradora, cujos objetivos eram explorar mão de obra e educar para o trabalho. Em arquétipo econômico anterior, medieval, o sistema prisional não existe enquanto pena e, consequentemente, a detenção e a privação de liberdade, como mecanismo punitivo, também não. Nesse momento uma legislação penal sanguinária punia em excesso espetacular, fazendo uso muitas vezes de execuções, torturas e mutilações. O que se atesta é que, antes da modernidade, a prisão afirma-se como lócus temporário de sujeitos que aguardavam uma pena efetiva; a prisão assemelhava-se à uma prisão cautelar. Como assevera Dario Melossi e Massimo Pavarini (2006, p. 22):

Por conseguinte, na presença de um sistema socioeconômico como feudal, no qual ainda não se historicizara completamente a ideia do "trabalho humano medido no tempo" (leia-se, trabalho assalariado), a pena-retribuição, como troca medida pelo valor, não estava em condições de encontrar na provação do tempo o equivalente do delito. O equivalente do dano produzido pelos delitos se realizava, ao contrário, na privação daqueles bens socialmente considerados como valores: a vida, a integridade física, o dinheiro, a perda de status.

A partir do século XVI e sua correlata economia mercantilista, suplente da economia feudal, assevera-se que o declínio demográfico europeu, proveniente de guerras e pestes, reflete diretamente em uma escassa força de trabalho. É nesse momento que o cárcere surge como instituição apta moralmente a explorar mão de obra não remunerada. Nesse contexto surge as workhouses, casas de trabalho que possuíam um escopo educacional, como forma de enfrentar a vagabundagem, a mendicância e o banditismo, bem como um escopo laboral e trabalhista, como forma de utilizar essas massas como mão-de-obra. Em razão da emergente economia mercantilista que sofria com a escassez de força de trabalho, devido ao declínio demográfico e consequente valorização da força de trabalho, a workhouse desempenhou também papel fundamental como medida regularizadora de salários. $\mathrm{O}$ encarceramento punitivo volta-se para as 
classes populares como medida também econômica, uma vez que matá-las e mutilá-las revelavase, naquele momento, contraproducente para o sistema, visto que essas massas insurgentes tornar-se-iam, depois de disciplinadas, mão-de-obra abundante para os empreendimentos econômicos emergentes.

Neste estágio econômico, as táticas de punição brutais do período pré-moderno não se desvaneceram por completo, todavia, inaugurava-se sua transmutação rumo às casas de trabalho como singular mecanismo punitivo. Em razão desse fenômeno, assevera-se o modelo lucrativo e frutífero que as workhouses conquistam em virtude da inserção do trabalho nessas localidades e à nova economia manufatureira. Evidente, portanto, que o cárcere moderno, enquanto mecanismo punitivo, está intrinsecamente atrelado às workhouses manufatureiras. Como assegura Melossi (2006b, p. 13):

O cárcere tivera como antepassado a "casa de trabalho", espécie de manufatura reservada às massas que, expulsas dos campos, afluíram para as cidades, dando lugar a fenômenos que preocupavam as elites mercantis (e proto-capitalistas) da época: banditismo, mendicância, pequenos furtos e, last but not least, recusa a trabalhar nas condições impostas por essas elites. A casa de trabalho - um "proto-cárcere" que seria depois tomado como modelo da forma moderna do cárcere no período iluminista, isto é, quando ocorreu a verdadeira "invenção penitenciária" - não parecia ser outra coisa senão uma instituição de adestramento forçado das massas ao modo de produção capitalista; afinal, para elas, esse modo de produção era uma absoluta novidade (e, nesse sentido, a casa de trabalho era uma instituição 'subalterna' à fábrica).

Melossi e Pavarini também se certificam da interdependência do modelo capitalista moderno, e seu motor industrial, concatenado ao sistema punitivo. Os autores atestam que a correlação entre punição e economia não esgota toda a reflexão. É preciso compreender que as workhouses não possuíam exclusivamente o fito de utilizar essas massas como mão-de-obra em virtude da emergente economia mercantilista. Tampouco se resumia ao propósito de regularizar e manter os salários baixos. A disciplina, a dominação e a domesticação, bem como o aprendizado da nova ordem laboral, são igualmente relevantes para o assujeitamento das massas proletárias. Para os autores, ainda que as casas de trabalho estivessem de fato concatenadas às estruturas sociais, essas instituições estavam atreladas, antes de tudo, à instrução da insólita disciplina que torna a massa proletária o quanto mais dócil. É nesse sentido que Melossi (2006a, p. 67) atesta que:

O regulamento interno da casa, além, de garantir um standard de vida que é, às vezes, inferior ao do cárcere, impõe uma série de limitações à liberdade pessoal, que é típica do cárcere; ademais, e esse aspecto é particularmente significativo, o trabalho ali desenvolvido é, em geral, inútil, insignificante, pensado muito mais em função das exigências da disciplina e da domesticação do que em termos de rendimento produtivo.

Outrossim, para os autores de Cárcere e fábrica, a doutrina calvinista e sua ética de trabalho é um pilar relevante no que concerne a introdução do dogma laboral e trabalhista nas casas de trabalho, bem como a ideologia burguesa-calvinista com o intento de naturalizar o modo de produção capitalista e o processo de exploração desses sujeitos. Mais do que acreditar que as casas de trabalho, e consequentemente o cárcere, produziriam mercadorias mediante o trabalho imbricado nestas instituições, deve-se acreditar que estas instituições produziriam sujeitos disciplinados ao trabalho fabril. Sujeitos transmutados, pela disciplina e concepção burguesacalvinista de vida, em sujeitos docilizados aptos à exploração. 
Nesse estágio, a detenção dos vagabundos e desordeiros nas workhouses possuía o escopo de domesticar o corpo e docilizar a alma do sujeito, incutindo-os a lógica disciplinar e tornando-os aptos à reprodução da lógica do trabalho. Neste sentido, argumenta Michel Foucault (2014, p. 213):

[...] os dois processos, acumulação de homens e acumulação de capital, não podem ser separados; não teria sido possível resolver o problema da acumulação de homens sem o crescimento de um aparelho de produção capaz ao mesmo tempo de mantê-los e de utilizá-los; inversamente, as técnicas que tornam útil a multiplicidade cumulativa de homens aceleram o movimento de acumulação do capital. [...] As mutações tecnológicas do aparelho de produção, a divisão do trabalho, e a elaboração das maneiras de proceder disciplinares mantiveram um conjunto de relações muito próximas. Cada uma das duas tornou possível a outra, e necessária: cada uma das duas serviu de modelo para a outra.

Sob essa perspectiva e arquétipo moderno, cabe assegurar, portanto, que a prisão aglutinou sujeitos que se encontravam em posição de mão-de-obra, vale dizer, nesse espaço de punição moderna o sujeito detido era considerado útil face aos insurgentes empreendimentos econômicos. Enquanto sujeito apenado era, na verdade, assimilado pela lógica disciplinar que o orientava para o novo modo de produção.

Encarcerar nesse contexto significava, em princípio, explorar trabalho, mas com o passar do tempo, refletido na crescente oferta de mão de obra livre para a atividade fabril, a utilidade maior foi se transmutando para o eficiente treinamento laboral. Dito de outro modo, após certo desenvolvimento industrial, o objetivo final do cárcere não mais se limitou a lucrar com o confinamento, ainda que em seu início esse tenha sido um dos propósitos fundamentais.

O modelo disciplinar de punição começa a formatar um discurso que apregoava a necessidade de assimilar o desviante através do treinamento para uma nova ordem. Embora, no início do século XVI, a pena privativa de liberdade tenha sido um subterfúgio para garantir mão de obra industrial em momentos de escassez, a justificativa política que se destacava era justamente o caráter reformador característico da prisão. Essa justificativa vai perdurar até o fim do século XX (PASTANA, 2012, p. 534).

Ademais, nesse momento o encarceramento não devia, de maneira alguma, inviabilizar a oferta de mão de obra livre, ou seja, em pleno desenvolvimento industrial moderno, o cárcere passa a ser locus temporário de reeducação, sem propriamente, feições empreendedoras. Sua justificativa é reformar sujeitos desviantes incutindo em suas mentes a importância de se dedicar ao trabalho. Além disso, encarcerar passa a ser considerado um mecanismo de controle cada vez mais oneroso e que, portanto, deveria ser utilizado de maneira racionalizada. Em dado momento o cárcere passa a ser medida excepcional como explica Cláudio Guimarães (2007, p 33):

Quer-se fazer crer, portanto, que a pena privativa de liberdade deve ser aplicada de forma bastante comedida em razão dos altos custos financeiros que a mesma acarreta para a sociedade. A construção, equipamento e manutenção das instalações penitenciárias, além da perda econômica que se supõe manter milhares de pessoas inativas e alheias ao processo produtivo, posto que alijadas de suas profissões habituais desautorizam o indicativo de política criminal alicerçado na aplicação da pena de prisão. 
Percebe-se, portanto, que em boa parte da modernidade o detento foi considerado sujeito, cuja característica primordial, que o colocava no centro do controle social, estava representada pela função de ser mão de obra por excelência de uma economia em pleno desenvolvimento. O cárcere teve funções bem definidas diante dessa característica. Primeiro foi espaço de expropriação, depois local de treinamento. Em todas as fases o preso nunca deixou de ser mão de obra, ora explorada, ora treinada.

\section{PUNIÇÃO E ECONOMIA NA CONTEMPORANEIDADE}

Em um salto histórico marcado por profundas transformações econômicas e sociais, observamos nas últimas duas décadas do século XX e, principalmente, no início do século XXI, uma mudança radical na economia e na significação do sujeito objeto de punição. Mais do que isso, percebemos como opera-se a descaracterização do indivíduo no processo punitivo, que o leva paulatinamente a não mais figurar como sujeito.

Neste começo de século significativas transformações estruturais em todo o globo interferiram de maneira direta na economia mundial, o que, por sua vez, trouxe consigo notáveis modificações nas políticas estatais de cada país. A eclosão de uma agenda neoliberal atingiu várias democracias no Ocidente de maneira intransigente, intervindo, ademais, nas políticas criminais desses países ${ }^{1}$.

Da modernidade à contemporaneidade, certifica-se uma profícua reestruturação estatal em matéria social e punitiva. De um Estado que, outrora, possuía casas de correção e casas de trabalho, bem como as insurgentes prisões posteriores; cujo mecanismo punitivo detinha-se no escopo de punir os indivíduos intentando discipliná-los e reeduca-los para a ordem do trabalho; para uma constelação de prisões contemporâneas que refletem apenas a exploração econômica da detenção, processo independente da reeducação do detento.

Diante de todas as reconfigurações político-econômicas do Estado, vale dizer, neoliberalismo, globalização, reestruturação do capital e da produção, reestrutura-se hodiernamente, também, seus mecanismos punitivos.

Na modernidade, impossível seria a dissociação entre capital e trabalho, dado que tanto a massa trabalhadora quanto o industrial dependiam da lógica produtiva fordista.

O divórcio não era uma solução realista [...] O poder e a riqueza de Ford não eram mais extensos nem mais sólidos do que suas imensas fábricas, suas pesadas máquinas e sua massiva força de trabalho; ele não podia se dar ao luxo de perder qualquer uma delas" (BAUMAN, 2003, p. 35).

Em uma única máxima, o trabalho era um pilar de sustentação da modernidade. "Usado para construir a identidade do homem moderno, ele surgiu como resultado da consolidação da Revolução Industrial e resistiu por séculos" (BAUMAN; BORDONI, 2016, p. 141).

Contudo, na contemporaneidade o trabalho já não é capaz de assegurar-se como um pilar sólido de sustentação face inúmeras outras formas de acumulação fictícias. Por outro lado, é a capacidade de consumir que dá sentido à existência do sujeito e, mesmo, constrói sua identidade e status no atual momento. "O consumismo se preparou para adquirir maior importância em

\footnotetext{
${ }^{1}$ Neste sentido, Debora Pastana assegura que "nos últimos trinta anos transformações significativas que afetaram o perfil da economia mundial começaram a despontar, acarretando também mudanças na configuração política dos estados e nas formas de sociabilidade. [...] Reestruturação produtiva, liberação dos mercados, privatização de indústrias e serviços, desregulamentação das relações de trabalho, flexibilização salarial, desemprego estrutural e redução das políticas públicas de inclusão social são apenas algumas das características desse limiar neoliberal. O fato é que o mundo está cada vez mais diligente com a economia e menos preocupado com o social. Na esfera da criminalidade e dos mecanismos de controle relacionados ao desvio, o período também foi marcado por uma série de alterações consideradas retrocessos políticos para muitos estudiosos do tema" (PASTANA, 2013, p. 30).
} 
relação à produção e para tornar-se, na modernidade tardia, a grande alternativa ao próprio trabalho" (BAUMAN; BORDONI, 2016, p. 144). Em consequência, com o declínio do trabalho enquanto ideal, o cárcere também já não possui o intento de reeducar os sujeitos para a ordem laboral, menos ainda é capaz de reintegrar os sujeitos para a tenra ordem consumerista. Isto posto, os métodos punitivos transmutam-se em mecanismos para lidar com sujeitos descartados ou descartáveis da nova ordem econômica, vale dizer, os sujeitos inúteis, desempregados e totalmente à margem do consumo. Nesse contexto, o cárcere vislumbra-se como depósito de rejeitos humanos em virtude da inutilidade que ofertam à ordem econômica corrente.

A crise do paradigma disciplinar da modernidade, bem como suas tecnologias de disciplinamento, revela, de fato, esse novo arquétipo. Hodiernamente, o intento da nova política criminal é neutralizar as massas depauperadas consideradas perigosas, prevenindo o risco, mediante segregação, vigilância e encarceramento em massa. Zygmunt Bauman atesta que, diametralmente oposto ao arquétipo moderno que utilizava os sujeitos como mão-de-obra em virtude da emergente economia capitalista; no atual arquétipo econômico neoliberal, "as fábricas de imobilidade" despontam como lugares de pura contenção de desviantes. As prisões não são mais projetadas como "fábrica de disciplina ou do trabalho disciplinado", mas como "fábrica de exclusão de pessoas habituadas à sua condição de excluídas", não importando o que façam nesses locais, desde que permaneçam ali, imóveis (BAUMAN, 1999, p. 121).

Nessas condições, o confinamento não é nem escola para o emprego nem um método alternativo compulsório de aumentar as fileiras da mão de obra produtiva quando falham os métodos "voluntários" comuns e preferidos para levar à órbita industrial aquelas categorias particularmente rebeldes e relutantes de "homens livres". Nas atuais circunstâncias, o confinamento é antes uma alternativa ao emprego, uma maneira de utilizar ou neutralizar uma parcela considerável da população que não é necessária à produção e para a qual não há trabalho "ao qual se reintegrar". [...] Em outras palavras, o que se faz necessário são novas condições que favoreceriam hábitos e atitudes diametralmente opostos àqueles que a ética do trabalho professava e que eram promovidos pelas instituições panópticas encarregadas de implementar essa ética. Os trabalhadores devem desaprender a dedicação ao trabalho duramente adquirida e o apego emocional duramente conquistado ao local de trabalho, assim como o envolvimento pessoal no conforto desse ambiente (BAUMAN, 1999, p. 119120).

A prisão, que desde a modernidade possuía atributos instrumentais e simbólicos concernentes a sua correlação com as estruturas político-econômicas, atualmente projeta-se como instituição que detém o poder de imobilizar massas carcerárias e ao mesmo tempo lucrar economicamente com tal confinamento, agora apenas neutralizador. Nesse estágio contemporâneo de reestruturação capitalista, o visível aumento das taxas de desemprego, especialmente nos países que outrora possuíam políticas de bem-estar social, sinaliza para o crescente número de mão de obra supérflua e potencialmente desviante. Isso porque tal reestruturação acarreta em grande medida a expulsão de pessoas que não mais se adequam à ordem econômica e revelam-se desqualificadas. Tais indivíduos expulsos do processo produtivo, e à margem das qualificações do mercado, revelam-se úteis apenas na exploração econômica do controle e da punição (GIORGI, 2006, pp. 47-48).

Assim, "no plano mais baixo da escala social, o encarceramento serve para neutralizar e estocar fisicamente as frações excedentes da classe operária, notadamente os membros despossuídos dos grupos estigmatizados" (WACQUANT, 2007, p. 16).

O que hoje se verifica é uma massa de trabalhadores expulsos do processo produtivo, uma vez que se desvela excessiva e inútil, todavia, submetida ao controle e não mais à disciplina. $\mathrm{O}$ encarceramento em massa da excessiva força de trabalho supérflua, vítima do desemprego

Revista de Direito Brasileira | São Paulo, SP | v. 18 | n. 7 | p. 374 - 392 | Set./Dez. 2017 
estrutural contemporâneo, ressignifica seu posicionamento no processo punitivo. Como assevera Alessandro de Giorgi (2006, p. 96), os sujeitos desafortunados, vale dizer, o excesso de mão-deobra proveniente da reestruturação capitalista pós-fordista, são administrados não mais pelos instrumentos de regulação social, mas pelos instrumentos de repressão penal.

A correlação entre punição e economia que se propala no presente momento, sob as transmutações estruturais que trazem consigo um ideal neoliberal atrelado a um capital não mais industrial, mas fictício em escala global, é profundamente alterada. À desregulamentação econômica, acompanhada do não investimento social, corresponde uma hiper-regulação e superinvestimento penal. As democracias alinhadas a esse paradigma, além de regradas pela ideologia neoliberal, inclinam-se cada vez mais no sentido de minimizar seu Estado Social e maximizar seu Estado Penal. Para tanto se utilizam de mecanismos punitivos para mitigar os empecilhos provenientes de sua própria ausência social.

Assim, a "mão invisível" do mercado do trabalho desqualificado encontra seu prolongamento ideológico e seu complemento institucional no 'punho de ferro' do Estado penal, que se amplia e se desdobra de modo a jugular as desordens geradas pela difusão da insegurança social e pela desestabilização correlata das hierarquias estatutárias que configuravam a armadura tradicional da sociedade nacional. [...] A regulação das classes populares, levada adiante por aquilo que Pierre Bourdieu chama de "mão esquerda" do Estado - a que protege e melhora as oportunidades de vida, e é representada pelo direito ao trabalho, à educação, à saúde, à assistência social e à moradia pública -, é suplantada (nos Estados Unidos) e suplementada (na União Européia) pela regulação da sua "mão direita", que administra a polícia, a justiça e a prisão, cada vez mais ativa e interveniente nas áreas subalternas do espaço social e urbano (WACQUANT, 2007, p. 32).

Consequentemente, as políticas criminais, assim como os mecanismos punitivos, transfiguram-se mais austeros, atreladas a altos índices de criminalização e encarceramento das massas miseráveis que pouco podem contribuir com a insólita ordem econômica. Esse Estado Punitivo $^{2}$, que atua mediante uma postura austera e intransigente face aos empecilhos emanados de sua própria ausência social, utiliza-se amplamente do recurso de encarceramento em massa, precipuamente dos membros das classes populares. O que é passível de se contemplar, no Brasil, é uma população carcerária que se expandiu à níveis colossais desde a reabertura política ${ }^{3}$. Não sem razão, Vera Regina Pereira de Andrade (2012, pp. 247-248) assevera que:

Ao Estado neoliberal mínimo no campo social e da cidadania, passa a corresponder um Estado máximo, onipresente e espetacular, no campo penal. [...] Os déficits de dívida social e cidadania são ampla e verticalmente compensados com excessos de criminalização; os déficits de terra, moradias, educação, estradas, ruas, empregos, escolas, creches e hospitais, com a

\footnotetext{
${ }^{2}$ De acordo com Pastana (2013, p. 27), o Estado Punitivo pode ser concebido como uma "figura política que se ajusta às transformações econômicas, sociais e culturais já em curso nos últimos trinta anos e que desponta no Brasil como forma cada vez mais hegemônica de controle social”. Essa concepção de Estado, sob o contexto brasileiro, é proveniente da hodierna postura nacional de controle ostensivo e truculento da criminalidade que, atrelada às forças contemporâneas neoliberais e neoconservadoras, é responsável, por exemplo, pela indeterminação de conceitos como democracia e autoritarismo (PASTANA, 2013).

${ }^{3}$ Conforme o levantamento nacional de informações do Departamento Penitenciário Nacional (DEPEN), em junho de 2014 a população prisional brasileira encontrava-se com 607.731 presos em sua totalidade. Se comparado com o início dos anos noventa, quando a população prisional contabilizava cerca de 90.000 presos, esse número representa um crescimento de aproximadamente 575\%. Com estrutura de 376.669 vagas, o sistema prisional revelava um déficit de 231.062 vagas, bem como aufere ao Brasil a posição de quarto lugar no que se refere a população prisional mundial, perdendo tão somente para os Estados Unidos, China e Rússia.
}

Revista de Direito Brasileira | São Paulo, SP | v. 18 | n. 7 | p. 374 - 392 |Set./Dez. 2017 
multiplicação de prisões; a instrumentalidade da Constituição, das leis e dos direitos sociais com o simbolismo da lei penal; a potencialização da cidadania com a vulnerabilidade à criminalização. [...] O Estado, impossibilitado de oferecer soluções instrumentais e democráticas para a conflitividade crescente gerada pelas condições excludentes do poder econômico globalizado e agravada por sua própria ausência, produz um espetáculo continuado de soluções simbólicas, sendo um dos meios preferidos do Estado-espetáculo a produção de leis que prometem mais direitos e mais soluções, notadamente penais, para solucionar o gigante da criminalidade que ele próprio cria.

A minimização do Estado Social por certo provoca a maximização de um Estado Punitivo de caráter autoritário e seletivo que acarreta a precarização da cidadania, reduzindo o controle social à mera orientação punitivista. Sem embargo à todas essas considerações, Loïc Wacquant (2001, p. 7) atesta que "a penalidade neoliberal apresenta o seguinte paradoxo: pretende remediar com um 'mais Estado' policial e penitenciário o 'menos Estado' econômico e social que é a própria causa da escalada generalizada da insegurança objetiva e subjetiva em todos os países". A política primordial é gerenciar, controlar e eliminar as massas depauperadas mediante medidas penais autoritárias, concatenadas e justificadas em virtude da tenra ordem neoliberal.

O Estado, que se retira e se exime de suas funções em nível social e econômico auferindo essas atribuições ao mercado -, bem como amplia e estende suas funções e mecanismos penais e punitivos, reconfigura suas próprias características e transmuta-se em novo arquétipo estatal, agora reformulado em virtude das novas máximas neoliberais globalizadas. Nesse sentido, hodiernamente vislumbra-se um Estado que se revela extremamente apartado de seus encargos à nível coletivo e financeiro, mas que se desnuda extremamente intransigente e autoritário no que se refere ao controle e punição das desordens insurgentes. Não sem razão, assegura Wacquant (2007, pp. 88-89) que:

Esse Estado-centauro, guiado por uma cabeça liberal, montada num corpo autoritário, aplica a doutrina do laissez-faire et laissez-passer a montante, em relação às desigualdades sociais, aos mecanismos que as geram (o livre jogo do capital, desrespeito do direito do trabalho e desregulamentação do emprego, retração ou remoção das proteções coletivas), mas mostra-se brutalmente paternalista e punitivo a jusante, quando se trata de administrar suas consequências em nível cotidiano.

Esse arquétipo de Estado que se revela mínimo em matéria social e máximo em matéria penal, não apenas atua no recrudescimento das políticas criminais, mas principalmente por meio de uma seletividade institucional cujo alvo principal é a camada mais empobrecida da ordem social. Ademais, Katie Argëllo (2012, p. 207) evidencia que nas últimas décadas houve um recrudescimento dos mecanismos punitivos por via das políticas criminais e legislações penais, qualificando-as como legislações que expressam tão somente o desejo de vingança orquestrado pelo discurso da 'lei e da ordem'. Nesse sentido certifica-se David Garland (2008, p. 57) que, "o processo de formulação das políticas se tornou profundamente politizado e populista".

No que se refere ao declínio do ideal de reabilitação, assevera-se que se abriu novamente espaço para ideais de retribuição das medidas punitivas, neutralização dos sujeitos passíveis de serem encarcerados, bem como gerenciamento dos riscos suscitados hodiernamente. O ideal de reabilitação e toda sua racionalidade, que outrora foi o pilar estruturante de todo o sistema penalpunitivo moderno, reproduzia-se mutuamente. No momento em que esse ideal extirpou-se, todo o arquétipo, valores e práticas em que a pena moderna foi emergida também retrocederam (GARLAND, 2008, p. 51). 
Assim como aqueles que são excluídos do trabalho, os criminosos (ou seja, os que estão destinados à prisão, já estão presos, vigiados pela polícia ou simplesmente fichados) deixaram de ser vistos como excluídos provisoriamente da normalidade da vida social. Não são mais encarados como pessoas que seriam "reeducadas", "reabilitadas" e "restituídas à comunidade" na primeira ocasião, mas vêem-se definitivamente afastadas para as margens, inaptas para serem "socialmente recicladas": indivíduos que precisam ser impedidos de criar problemas e mantidos a distância da comunidade respeitosa das leis (BAUMAN, 2009, pp. 24-25).

Em um período de capitalismo truculento, desemprego estrutural, insegurança social e economia neoliberal, a prisão, mais do que revelar-se espaço de alocação de sujeitos inúteis, também se apresenta como uma medida de controle lucrativa das ilegalidades dos miseráveis globais. Como assegura Wacquant (2001, p. 93):

Ao mesmo tempo, a implantação das penitenciárias se afirmou como um poderoso instrumento de desenvolvimento econômico e de fomento do território. [...] As prisões não utilizam produtos químicos, não fazem barulho, não expelem poluentes na atmosfera e não despedem seus funcionários durante as recessões. Muito pelo contrário, trazem consigo empregos estáveis, comércios permanentes e entradas regulares de impostos. A indústria da carceragem é um empreendimento próspero e de futuro radioso, e com ela todos aqueles que partilham do grande encarceramento dos pobres nos Estados Unidos.

Nesse arquétipo em que punição e economia se encontram, hodiernamente, atreladas a um capital global proveniente de um modelo econômico neoliberal, a privatização prisional revela-se um fenômeno promissor. Perfeitamente adequada à racionalidade neoliberal, a privatização revela-se ainda mais funcional na medida em que almeja lucrar com o controle. É a máxima neoliberal levada à última consequência, vale dizer, não apenas o cárcere funciona como mecanismo de controle, mas passa a gerar lucro para o Estado e para a iniciativa privada. Mai uma vez percebe-se a relação direita entre cárcere e fábrica. Ainda que agora o produto final seja absolutamente diferente.

Ao introduzir o conceito de pós-democracia - crise de igualitarismo e banalização do processo democrático, em que a política deteriora seu contato com os cidadãos e, consequentemente, gera o que se poderia denominar de "antipolítica" (BAUMAN; BORDONI, 2016, p. 166) -, Carlo Bordoni (2016, p. 169) atesta que um dos efeitos que caracterizam o atual arquétipo pós-democrático seria, dentre outras, a "privatização em nome do progresso, do lucro e da eficiência".

Ao fazer uso do propósito comercial para lidar com o sistema prisional e, por consequência, eximindo-se de suas responsabilidades e atribuições, o Estado é capaz de reduzir os custos orçamentários para um setor relegado à margem da esfera de preocupação políticosocial. No que se refere as prisões com finalidade lucrativas norte-americanas, Wacquant (2007, p. 288) certifica-se de que esse é um fenômeno corrente e obrigatório para o atual arquétipo penal-punitivo, gerando uma desenfreada competição de empresas privadas no que versa a licitação da privatização prisional. Consequentemente, não apenas as empresas privadas lucram com a privatização, mas também as parcerias público-privadas, essas que fornecem bens e serviços ao sistema prisional, perpassando desde alimentação e vestuários dos encarcerados, até à vigilância, controle e administração dos mesmos.

Nesse paradigma, a gestão privada do cárcere torna o desvio, e o posterior encarceramento dos desviantes, mecanismos voltados para a obtenção de lucro. Consequentemente, à medida que se obtêm mais indivíduos encarcerados, mais o cárcere desvela-se promissor, frutífero e lucrativo. O cárcere, como indústria do controle do crime, torna- 
se um negócio privado atrelado à produção, tornando o sujeito criminalizado não mais apto a receber disciplinamento e posterior regeneração, mas tão somente destinado a receber investimento privado. Isso redefine seu papel no processo punitivo. Além disso, lhe tira o caráter de sujeito. O desviante deixa de ser sujeito explorado para ser insumo, matéria prima. Sua condição se altera radicalmente. Ele é reduzido em sua condição de sujeito, muito na esteira do que discute Giorgio Agamben sobre o novo paradigma político estatal.

[...] decisivo é, sobretudo, o fato de que, lado a lado com o processo pelo qual a exceção se torna em todos os lugares a regra, o espaço da vida nua, situando originariamente à margem do ordenamento, vem progressivamente a coincidir com o espaço político, e exclusão e inclusão, externo e interno, bíos e zoé, direito e fato entram em uma zona de irredutível indistinção. $\mathrm{O}$ estado de exceção, no qual a vida nua era, ao mesmo tempo, excluída e capturada pelo ordenamento, constituía, na verdade, em seu apartamento, o fundamento oculto sobre o qual repousava o inteiro sistema político; quando as suas fronteiras se esfumam e se indeterminam, a vida nua que o habitava libera-se na cidade e torna-se simultaneamente o sujeito e o objeto do ordenamento político e de seus conflitos, o ponto comum tanto da organização do poder estatal quanto da emancipação dele (AGAMBEN, 2010, p. 16).

Em virtude desse hodierno arquétipo político-econômico, emerge uma nova categoria de criatura humana que possui uma vida indigna, sem valor e que não merece ser vivida, vale dizer, uma vida nua, sacrificável e potencialmente passível de aniquilação. Uma vida banalizada e politicamente à margem dos direitos e garantias constitucionais estabelecidos em muitas nações. É nesse sentido que Agamben (2010, p 175) alerta para o fato de que “(...) o projeto democráticocapitalista de eliminar as classes pobres, hoje em dia, através do desenvolvimento, não somente reproduz em seu próprio interior o povo dos excluídos, mas transforma em vida nua todas as populações do Terceiro Mundo". No mesmo sentido, Minhoto adverte que (2000, p. 196):

Se a prisão foi institucionalizada no mundo moderno para gerenciar as ilegalidades das classes menos abastadas, atendendo aos requerimentos da sociedade fabril em formação, em tempos de capitalismo turbinado ela continua a desempenhar basicamente o mesmo papel, ao monitorar e apenar os novos "sujeitos monetários sem dinheiro", devidamente descartados da nova ordem econômica internacional, para reinseri-los na qualidade de consumidores cativos da indústria da punição, no admirável mundo novo do panopticon mercantilizado.

Ora, a privatização do cárcere contemporâneo, coerente com o paradigma neoliberal em curso, torna a prisão lócus de contenção dessa massa miserável e indesejável da sociedade gerando, ao mesmo tempo, emprego, renda e capital lucrativo para muitos; estimulando assim um modelo político-econômico baseado tão somente em predileções eficientemente econômicas, típicas do neoliberalismo. "No plano político-institucional, as prisões privadas ajustam-se perfeitamente ao projeto neoliberal de redução da presença do Estado na esfera do bem-estar e de ampliação das estratégias da lei e da ordem" (MINHOTO, 2002, p. 144).

A defesa cada vez mais contundente de um sistema prisional privatizado está ancorada na justificativa política amplamente difundida de que o Estado não seria mais capaz de fomentar economicamente um sistema inchado e caro. A reprodução de um discurso político hegemônico que atesta a existência de uma grande crise do sistema penitenciário, na realidade, encobre o declínio do ideal ressocializador e a atrativa expectativa de lucratividade desse setor ainda passível de enorme expansão. Tal discurso vem refletindo o ideário neoliberal em curso e os modelos de segurança privada, as experiências estrangeiras, notadamente estadunidenses e 
britânicas, assim como a ideologia de lei e ordem que propõe maior recrudescimento punitivo (RODRIGUES, 1995) ${ }^{4}$.

A privatização dos presídios, postulada por empresas de segurança interessadas tão somente em expandir seus campos de atividade e lucros, revela a maneira como esta reestruturação econômica em curso anula uma série de direitos fundamentais, e, por meio das forças do mercado, aniquila o arquétipo jurídico-político do próprio Estado democrático de direito. Tendo como pressuposto a situação caótica do sistema prisional, assim como o déficit de vagas, aqueles que postulam pela privatização oferecem-se para construir e administrar por conta própria os novos cárceres - privatizados e lucrativos - desde que o Estado os gratifique com uma quantia fixa por preso. A alegação auferida é a economicidade 5 (FARIA, 2000, p. 13).

No que versa à experiência brasileira, já é possível perceber a presença de empresas privadas que lucram com o fornecimento de serviços variados dentro do cárcere. Inseridas nas correntes transformações neoliberais, tais empresas lucram com o encarceramento independentemente de qualquer trabalho realizado dentro do cárcere pelos detentos. $\mathrm{O}$ encarceramento, por si só produz a lucratividade.

É importante ressalvar primeiramente que a maioria das propostas de privatização do sistema prisional no País está atrelada não somente à importação da experiência estrangeira, mas principalmente à atual reestruturação do capital globalizado e neoliberal. Além disso, tais propostas estão também concatenadas às características estruturalmente autoritárias que permeiam a história brasileira ${ }^{6}$ (MINHOTO, 2000). Ora, "a resolução de conflitos a partir de uma lógica privada que sanciona uma violência como padrão de comportamento socialmente válido e disseminado figura no centro da constituição de uma sociabilidade autoritária" (MINHOTO, 2000, p. 187).

Embora o Brasil ainda não assista a uma efervescência produtiva nessa área, de forma tímida as prisões também constituem um mercado atraente para os grupos privados. Entre nós a privatização de presídios realiza-se mais precisamente na forma de terceirização de serviços realizada através das parcerias públicoprivadas (PPPs), a mais recente modalidade de investimentos em infra-estrutura no país. Os governos estaduais assinam contratos com empresas privadas para gerenciamento da acomodação (vestuário, alimentação, limpeza), das instalações e da assistência médica e judicial, além do controle do dia-a-dia dos detentos. (...) Atualmente a maioria das penitenciárias do país possui algum tipo de

\footnotetext{
${ }^{4}$ É importante ressalvar que as propostas de privatização dos presídios esbarram em uma série de obstáculos, tais como éticos, jurídicos e políticos. Para João Marcello de Araújo Júnior (1995), os obstáculos éticos pautam-se pela impossibilidade de transferência do Estado a um terceiro a responsabilidade do poder de coação, sendo o Estado o detentor do monopólio legítimo da violência; os obstáculos jurídicos pautam-se pela impossibilidade de privatizar os presídios, uma vez que estes são lócus da execução penal que, por sua vez, integra a atividade jurisdicional estatal, portanto também indelegável; os aspectos políticos pautam-se na hipocrisia das empresas de segurança privada que não possuem o escopo de prevenir a criminalidade ou ressocializar o encarcerado, mas tão somente adquirir lucro com a privatização e consequentemente encarceramento.

5 Nas palavras de José Eduardo Faria (2000, p. 17) "muitos dos estabelecimentos penais geridos pela iniciativa privada convertem-se em depósitos de detentos, reproduzindo em maior escala os conhecidos problemas de agressões a presos, tráfico de drogas e falta de higiene e levando até os próprios porta-vozes do liberalismo globalizado, como a insuspeita revista The Economist, a perguntar se não valeria a pena reestatizá-los. Outras não obtiveram a lucratividade esperada, passando a reivindicar incentivos, créditos favorecidos e "complementações" de receita junto ao setor público".

${ }^{6} \mathrm{O}$ atual punitivismo brasileiro, materializado na sua histórica criminalização e encarceramento da miséria, agora está também atrelado à privatização do controle. Assim, finaliza-se mais um ciclo autoritário nacional, na medida em que nossa tão bem conhecida seletividade punitiva passa também a aniquilar todos aqueles miseráveis descartáveis frente à lógica capitalista dentro de presídios privados lucrativos.
} 
serviço terceirizado, sendo a alimentação o mais comum, feito através do fornecimento das tão conhecidas "quentinhas" (PASTANA, 2009, p.321).

Mais recentemente o governo de Minas Gerais, de forma pioneira, implementou um sistema de coadministração do sistema prisional mineiro, compartilhando-a com a iniciativa privada cujo escopo principal foi, precisamente, a obtenção de lucro. No ano de 2009, ao assinar um contrato que abrangia a construção e gestão de um complexo penitenciário no município de Ribeirão das Neves, região metropolitana de Belo Horizonte, o governo mineiro dá um passo largo em direção ao modelo de exploração econômica da punição que aqui estamos a tratar.

Tal complexo penitenciário, já em funcionamento desde janeiro de 2013, é gerenciado pela Gestores Prisionais Associados (GPA), uma sociedade de propósito específico (SPE) criada exclusivamente para esse fim. Explicando a natureza do contrato com a administração pública, assim se manifesta a GPA em sua página da Internet:

Uma Parceria Público-Privada é como o nome já diz, a união do Estado com um parceiro privado para juntos fazerem a administração de um empreendimento. É uma forma de viabilizá-lo sem que Estado faça qualquer investimento inicial (geralmente sempre muito alto) e remunera o parceiro privado pela construção e pelos serviços prestados em parceria com o próprio Estado. No caso de uma PPP no setor prisional, a coisa funciona da mesma forma. O CPPP é administrado pelo governo em parceria com a GPA, empresa privada que conquistou o direito de ser a parceira do Estado no empreendimento (sic) (Gestores Prisionais Associados - GPA, 2016).

Segundo a GPA, seu trabalho é transformador tendo "total ênfase na reinserção do preso à sociedade", além de se basear "em alguns pilares como respeito pelo preso e seus familiares desde o primeiro momento na unidade prisional, alto grau de segurança e tecnologia de ponta" (GPA, 2016). Também em sua página virtual, a GPA assegura que existe para "prestar serviços de atendimento à pessoa em cumprimento de pena privativa de liberdade com qualidade, segurança, eficiência e sustentabilidade", atestando também que atua "promovendo a humanização do Sistema Prisional e a geração de valor para Presos, Família, Colaboradores, Acionistas, Estado e Sociedade (GPA, 2016). Por fim, ressalta também que:

A GPA confia na recuperação e na possibilidade de reinserção do preso à sociedade. Para isso, ela cumpre à risca a Lei de Execução Penal (LEP) e vai além: inova, integra e cria um ambiente transformador.

"A execução penal tem por objetivo efetivar as disposições de sentença ou decisão criminal e proporcionar condições para a harmônica integração social do condenado e do internado." - Artigo 1 da Lei de Execução Penal

Por isso investe fortemente em atividades que contribuam para preparar o preso para o retorno ao convívio na sociedade, proporcionando assistência e atendimentos de diversas naturezas como jurídica (em caráter complementar à Defensoria Pública), médica, odontológica, psicológica, social, educacional, laborativa, ocupacional e religiosa. (Gestores Prisionais Associados - GPA, 2016).

Ironias a parte, essa aparente preocupação com a "humanização do cárcere", tão recorrente nas falas da GPA, na realidade encobre um processo produtivo que ao final desumaniza o encarcerado. No documentário intitulado A chegada das penitenciárias privadas no Brasil, produzido pela Agência Pública de Jornalismo Investigativo, no ano de 2014, podemos observar de forma muito transparente como a privatização prisional de tal complexo penitenciário desemboca em uma forma predatória de exploração econômica do cárcere que estabelece uma 
relação desumanizante com o preso desde seu ingresso. A fala de Bruno Shimizu, coordenador do Núcleo de Situação Carcerária da Defensoria Pública de São Paulo, é emblemática nesse sentido:

Dentro desse movimento neoliberal a gente começa a privatizar os serviços públicos, a infraestrutura e agora isso chega ao seu cume com a privatização da violência, além disso, a privatização do sofrimento. É a mercantilização do sofrimento. Aquela pessoa presa deixa de ser uma pessoa, deixa de ter dignidade humana, para ser vista como uma mercadoria. (A chegada das penitenciárias privadas no Brasil, 2014)

Segundo Patrick Lemos Cacicedo, também coordenador do Núcleo de Situação Carcerária da Defensoria Pública de São Paulo, o recrutamento de trabalhadores nesse ambiente é extremamente desumano, pois faz uso de um aliciamento de quase escravidão ${ }^{7}$.

Eles vão querer na verdade escolher um perfil de preso que aceite se submeter a condições de trabalho não regidas pela CLT, isso tem que se deixar claro, e com um salário menor que o salário mínimo. Três quartos do salário mínimo, sendo que disso uma parte vai para custear as despesas do preso no presídio. (A chegada das penitenciárias privadas no Brasil, 2014)

A parceria público-privada de Ribeirão das Neves foi fundamentada pela necessidade de uma gestão mais eficiente e econômica ${ }^{8}$ das unidades do sistema prisional e melhor administração na custódia dos encarcerados, numa hipócrita tentativa de legitimar a

\footnotetext{
${ }^{7}$ Aqui fica evidente a crítica de Laura Machado de Oliveira (2016, p 170) ao destacar que "o Código Penal, em seu artigo 39 determina que o trabalho do preso seja sempre remunerado, além de que sejam garantidos os benefícios da Previdência Social. A remuneração sofrerá enfoques diversos a respeito do beneficiário do labor, uma vez que é possível ser realizado em favor da administração pública ou para a iniciativa privada. O trabalho efetuado em prol da administração pública, é claro, será remunerado pela própria administração. Já em relação a iniciativa privada, há custos menores de produção com o emprego dos apenados em função da não configuração da relação de emprego, portanto o trabalho do preso torna-se uma mão de obra muito barata para o empregador, porque se utiliza da força de trabalho nos doze meses do ano (pois não há direito a férias), não implica o pagamento do Fundo de Garantia do Tempo de Serviço (FGTS) e o pagamento do décimo terceiro salário, além do valor pago ao apenado ser menor do que o salário-mínimo nacional". Ainda é importante destacar que de acordo com a Lei de Execução Penal - LEP (Lei 7210/84) o detento trabalhador pode receber salário inferior ao salário mínimo e sequer recebe diretamente pelos serviços prestados, uma vez que seus vencimentos são destinados arbitrariamente aos ressarcimentos previstos na referida lei. Sobre o tema assim está disposto:

Art. 29. O trabalho do preso será remunerado, mediante prévia tabela, não podendo ser inferior a 3/4 (três quartos) do salário mínimo.

$\S 1^{\circ} \mathrm{O}$ produto da remuneração pelo trabalho deverá atender:

a) à indenização dos danos causados pelo crime, desde que determinados judicialmente e não reparados por outros meios;

b) à assistência à família;

c) a pequenas despesas pessoais;

d) ao ressarcimento ao Estado das despesas realizadas com a manutenção do condenado, em proporção a ser fixada e sem prejuízo da destinação prevista nas letras anteriores.

$\S 2^{\circ}$ Ressalvadas outras aplicações legais, será depositada a parte restante para constituição do pecúlio, em Caderneta de Poupança, que será entregue ao condenado quando posto em liberdade.

${ }^{8}$ Contrariando a tese de que a privatização prisional garante redução dos custos do Estado com os presos, pesquisadores do tema atestam valores bem mais altos dos que os exercidos nas prisões públicas. "Enquanto nas penitenciárias públicas o custo mensal varia de R\$ 1.300 a R\$ 1.700 por preso, em Ribeirão das Neves, em Minas Gerais, a primeira penitenciária privada do País, o repasse estatal é de R $\$ 2.700$. 'O Estado está pagando mais para fazer a mesma coisa. E a diferença disso é simplesmente a margem de lucro do administrador. Então, não faz qualquer sentido que a gente aposte em um modelo mais caro e que, se não é pior, é a mesma coisa do que o modelo público', criticou Bruno Shimizu, coordenador auxiliar do Núcleo Especializado de Situação Carcerária da Defensoria Pública do Estado de São Paulo" (Especialistas condenam proposta de privatização de presídios.
} Conectas Direitos Humanos. São Paulo, 2016).

Revista de Direito Brasileira | São Paulo, SP | v. 18 | n. 7 | p. 374 - 392 |Set./Dez. 2017 
ressocialização do sujeito condenado por meio do trabalho quase nada remunerado. $\mathrm{O}$ documentário mostra como Ribeirão das Neves se transformou em uma fábrica altamente lucrativa de bens relacionados ao próprio encarceramento, como uniformes de agentes penitenciários e encarcerados (calças, coletes e botinas); além de outros equipamentos como alarmes e circuitos de segurança. Em outras palavras essa é uma fábrica que produz material para sua auto reprodução, na medida em que o cárcere passa a ser consumidor cativo dos produtos produzidos no próprio cárcere. Exatamente como descreve Nils Christie (1998, p. 122):

A população potencialmente perigosa é afastada e colocada sob completo controle, como matéria-prima para uma parte do próprio complexo industrial que os tornou supérfluos e ociosos fora dos muros da prisão. Matéria-prima para o controle do crime ou, se quiserem, consumidores cativos dos serviços da indústria do controle.

José Adaumir Arruda da Silva (2016, pp. 131-132) constatou, ao analisar os gráficos e números do perfil dos condenados de Ribeirão das Neves, que os encarcerados ali são, em sua grande maioria, jovens que cometeram crimes sem violência e grave ameaça, embora condenados a penas longas. $\mathrm{O}$ autor atesta que os presos são cuidadosamente escolhidos em virtude desses fatores pois passam a ser considerados força de trabalho mansa e permanente, dado o bom comportamento e as condenações por tempo elevado respectivamente. Outrossim, para continuar em Ribeirão das Neves (cujo único benefício é não possuir superlotação), esse encarcerado explorado ainda é constantemente ameaçado, devendo zelar sempre pelo bom comportamento e produtividade, sob o risco de retornar ao presídio público.

Nesse tão lucrativo negócio o preso não mais pode ser considerado simples mão de obra barata, ele até produz, mas nas condições que o faz, mais se assemelha à matéria prima. De fato, não apenas suas condições de trabalho são desumanas, mas, principalmente, ele é parte do pacote de investimentos. Não é por outro motivo que no contrato de concessão da PPP de Ribeirão das Neves uma das obrigações do poder público é "garantir a demanda mínima de $90 \%$ da capacidade do Complexo Prisional", vale dizer, o estado garante a ocupação de pelo menos $90 \%$ das vagas (Governo, 2014).

Ora, em uma perspectiva cidadã e de valorização do ser humano, o Estado deveria atuar sempre na diminuição da violência institucional e do encarceramento, procurando outras vias possíveis de equacionar satisfatoriamente o desvio social. Jamais deveria garantir uma cota mínima de $90 \%$ de ocupação prisional para empresas privadas explorarem os lucros.

Quando o Poder Concedente na Parceria Público-Privada se obriga a garantir a ocupação de pelo menos $90 \%$ das vagas criadas pelo parceiro privado [...] contradiz todas as finalidades declaradas da pena, o que descortina a deslegitimação de todo o sistema. [...] Parece incongruente com a perspectiva da redução da criminalidade e de um sociedade mais pacífica, porquanto se deve manter o nível de aprisionamento para atender as regras do contrato. [...] Assim, a estipulação de ocupação mínima condiciona o aumento da criminalidade, incentiva o encarceramento em massa e contradiz o ideal ressocializador tão propalado para justificar a privatização de presídios, além de violar princípios básicos que sustentam o Estado Democrático de Direito (SILVA, 2016, pp. 134135).

Por certo que tais empresas já estabelecidas no ramo do controle prisional não investirão empenho e capital se não estiverem certas da potencialidade lucrativa do empreendimento carcerário. Como bem assevera Guimarães (2005, p 41): 
Nunca é demais lembrar que toda indústria para se estabelecer, previamente, estuda os limites da potencialidade de oferta da matéria prima a ser utilizada, para garantir seus lucros a curto, médio e longo prazos, visto que sabe da imprescindibilidade da oferta desta para continuação de suas atividades, que no caso presente são seres humanos criminalizáveis e/ou criminalizados. Assim sendo, todo o movimento que hodiernamente permeia o Direito Penal objetivando criminalizar condutas através de uma hiperinflação da edição de leis, aumentar penas, diminuir garantias e benefícios em sede de execução, entre outras medidas que possibilitam uma expansão da tipificação de condutas, assim como, o aumento do tempo de cumprimento de pena, com toda certeza atendem aos interesses da indústria do controle do delito.

Estamos, portanto, criando a indústria do preso. É ele quem gera lucro. E nesse sentido a lógica é prender cada vez mais. O encarcerado virou insumo de um negócio altamente lucrativo e em plena expansão no país. Dessa forma lhe retiramos a caracterização de sujeito. Ele é agora passa a ser um não-sujeito que mais se assemelha à matéria prima indispensável a multiplicação dos lucros na nova indústria do controle.

Para quem investe em determinado produto, no caso o produto humano preso, será interessante ter cada vez mais presos. Ou seja, segue-se a mesma lógica do encarceramento em massa. A mesma lógica que gerou caos e que justificou a privatização dos presídios. (Patrick Cacicedo, In. A chegada das penitenciárias privadas no Brasil, 2014).

\section{CONCLUSÃO}

Enfim, cada vez mais é possível perceber que cárceres se transformam em verdadeiras fábricas produzindo os mais variados bens de consumo destinados, principalmente, ao próprio encarceramento. A gestão desses empreendimentos econômicos prisionais lucra duas vezes, ou seja, lucra com a produção e também com a própria gestão institucional. É nessa segunda forma de lucrar que o encarcerado passa à condição de matéria prima, na medida em que sua simples presença dentro do cárcere já opera uma forma de produzir lucro independentemente de sua atividade laboral no interior do presídio

Hoje, ser um detento não significa apenas figurar como mão de obra que produz. À essa característica moderna se soma o fato de que também será objeto de contratação, vale dizer, será cláusula de garantia do bom negócio prisional. Assim ele se torna insumo, pois sua presença no cárcere já é suficiente para que empresas privadas possam auferir lucros em seus negócios jurídicos associados à administração das prisões. Além disso, o detento também garante o processo produtivo no interior do cárcere, uma vez que acaba sendo o consumidor cativo daquilo que produz, dando a certeza de que o que se produz dentro do cárcere continuará necessário

Como a própria GPA admite em sua página oficial na Internet, a prisão, nesse novo contexto, passa a ser um empreendimento e ela parceira do Estado na exploração desse negócio.

Lamentavelmente, o encarceramento lucrativo e em massa dos indivíduos inúteis e indesejáveis passa a ser cada vez mais aceito socialmente ainda que travestido do discurso da otimização orçamentária. Com a maciça propaganda de que presídios privatizados são mais sustentáveis e baratos, o que se opera é na verdade uma perversa desumanização daquele que está cumprindo pena privativa de liberdade.

O Brasil caminha nessa esteira de privatização perversa e desumanizante do cárcere, não apenas se desvencilhando de suas responsabilidades relacionadas ao controle prisional, mas acima de tudo, viabilizando uma grande indústria cada vez mais lucrativa e bem-sucedida. Essa grande indústria conquista seu lucro por meio da administração da vida nua dos não-sujeitos 
alocados nesse polo em transformação. Investindo na vida nua de não-sujeitos, essa grande indústria encarcera cada vez mais e, em virtude do lucro privatizado, retroalimenta um sistema que aspirará obter, por sua vez, cada vez mais não-sujeitos encarcerados. É um círculo vicioso e lucrativo.

O encarcerado nesse modelo prisional passa a figurar não mais como mão-de-obra, outrora típica da lógica disciplinar de trabalho moderno. Economicamente o sujeito transfigurou de posição. $\mathrm{O}$ encarcerado se encontra, nesse arquétipo contemporâneo neoliberal, em uma posição de não-sujeito, simples matéria-prima, desvelando-se útil tão somente para fomentar o mercado da privatização e, consequentemente, estimular o investimento privado.

\section{REFERÊNCIAS BIBLIOGRÁFICAS}

A CHEGADA das penitenciárias privadas no Brasil. Produção de Agência Pública De Jornalismo Investigativo. São Paulo, 2014. Audiovisual disponível em: https://www.youtube.com/watch?v=Hvko5EwlsOU. Acesso em 15 de novembro de 2016.

AGAMBEN, Giorgio. Homo Sacer: o poder soberano e a vida nua. Tradução de Henrique Burigo. 2. ed. Belo Horizonte: Editora UFMG, 2010.

ANDRADE, Vera Regina Pereira de. Pelas mãos da criminologia: o controle penal para além da (des)ilusão. Rio de Janeiro: Revan, 2012.

ARAÚJO JÚNIOR, João Marcello de (Org.). Privatização das prisões. São Paulo: Revista dos Tribunais, 1995.

ARGËLLO, Katie. Do estado social ao estado penal: invertendo o discurso da ordem. Discursos Sediciosos: crime, direito e sociedade, Rio de Janeiro: Editora Revan, ano 17, n. 19/20, p. 207230, 2012.

BATISTA, Vera Malaguti. Introdução crítica à criminologia brasileira. Rio de Janeiro: Revan, 2011.

BAUMAN, Zygmunt. Comunidade: a busca por segurança no mundo atual. Tradução de Plínio Dentzien. Rio de Janeiro: Zahar, 2003.

Zahar, 2009. . Confiança e medo na cidade. Tradução de Eliana Aguiar. Rio de Janeiro: Janeiro: Zahar, 2016.

; BORDONI, Carlo. Estado de crise. Tradução de Renato Aguiar. Rio de . Globalização: as consequências humanas. Tradução de Marcus Penchel. Rio de Janeiro: Zahar, 1999.

- O mal-estar da pós-modernidade. Tradução de Mauro Gama e Cláudia Martinelli Gama. Rio de Janeiro: Zahar, 1998. 
CARVALHO, Salo de. Criminologia crítica: dimensões, significados e perspectivas atuais. Revista Brasileira de Ciências Criminais (RBCCrim), São Paulo, v. 21, n. 104, p. 279-303, 2013.

CHRISTIE, Nils. A indústria do controle do crime: a caminho dos GULAGs em estilo Ocidental. Tradução de Luís Leiria. Rio de Janeiro: Forense, 1998.

Especialistas condenam proposta de privatização de presídios. Conectas Direitos Humanos, São Paulo, 2016. Disponível em: http://www.conectas.org/pt/noticia/42586-huffpost-brasilespecialistas-condenam-proposta-de-privatizacao-de-presidios-que-esta-no-senado. Acesso em 10 de julho de 2017.

FARIA, José Eduardo. Prefácio. In: MINHOTO, Laurindo Dias. Privatização de presídios e criminalidade: a gestão da violência no capitalismo global. São Paulo: Max Limonad, 2000.

FONSECA, David S. Assumindo riscos: a importação de estratégias de punição e controle social no Brasil. In: CÂNEDO, Carlos; FONSECA, David S. (Orgs.) Ambivalência, contradição $e$ volatilidade no sistema penal: leituras contemporâneas da sociologia da punição. Belo Horizonte: Editora UFMG, 2012.

FOUCAULT, Michel. Vigiar e punir: nascimento da prisão. Tradução de Raquel Ramalhete. 42. ed. Petrópolis: Vozes, 2014.

GARLAND, David. A cultura do controle: crime e ordem social na sociedade contemporânea. Tradução de André Nascimento. Rio de Janeiro: Revan, 2008.

GIORGI, Alessandro de. A miséria governada através do sistema penal. Tradução de Sérgio Lamarão. Rio de Janeiro: Revan, 2006.

GOVERNO DO ESTADO DE MINAS GERAIS. Secretaria de Estado de Defesa Social (SEDS). Complexo Penal. Contrato de Concessão Administrativa, 2014. Disponível em http://www.ppp.mg.gov.br/sobre/projetos-de-ppp-concluidos/ppp-complexo-penal. Acesso em 10 de novembro de 2016.

GESTORES PRISIONAIS ASSOCIADOS - GPA. Sobre a GPA. Disponível em http://www.gpappp.com.br/index.php/br/. Acesso em 15 de novembro de 2016.

GUIMARÃES, Cláudio Alberto Gabriel. Funções da pena privativa de liberdade no sistema penal capitalista. Rio de Janeiro: Revan, 2007.

. O caso Minas Gerais: da atrofia do Estado Social à maximização do Estado Penal. Revista do Ministério Público do Estado do Maranhão: Juris Itinera/ Procuradoria Geral de Justiça, São Luís, n. 12, jan./dez., 2005.

MELOSSI, Dario. A gênese da instituição carcerária moderna na Europa. In: MELOSSI, Dario; PAVARINI, Massimo. Cárcere e fábrica: as origens do sistema penitenciário (séculos XVI XIX). Rio de Janeiro: Revan, 2006a. 
. Discussão à guisa de prefácio: cárcere, pós-fordismo e ciclo de produção da "canalha". In: GIORGI, Alessandro de. A miséria governada através do sistema penal. Rio de Janeiro: Revan, 2006b.

; PAVARINI, Massimo. Cárcere e fábrica: as origens do sistema penitenciário (séculos XVI - XIX). Tradução de Sérgio Lamarão. Rio de Janeiro: Revan, 2006.

MINHOTO, Laurindo Dias. As prisões do mercado. Lua Nova, São Paulo, n. 55-56, p. 133-154, 2002.

- Privatização de presídios e criminalidade: a gestão da violência no capitalismo global. São Paulo: Max Limonad, 2000.

OLIVEIRA, Laura Machado de. O trabalho do apenado e a (des)marginalização do direito laboral. Revista de Direito Brasileira, São Paulo, v. 13. n. 6, jan./abr., 2016.

PASTANA, Debora Regina. Economia e punição: uma relação histórica na perspectiva das Ciências Sociais. Estudos de Sociologia, Araraquara, v. 17, n. 33, p. 529-547, 2012.

- Estado punitivo brasileiro: a indeterminação entre democracia e autoritarismo. Civitas, Porto Alegre, v. 13, n. 1, p. 27-47, jan-abr., 2013.

. Estado punitivo e encarceramento em massa: retratos do Brasil atual. Revista Brasileira de Ciências Criminais: RBCCrim, São Paulo, v. 17, n. 77, p. 313-330, mar-abr., 2009.

RODRIGUES, Geisa de Assis. Privatização de prisões: um debate necessário. In: ARAÚJO JÚNIOR, João Marcello de (Org.). Privatização das prisões. São Paulo: Revista dos Tribunais, 1995.

RUSCHE, Georg; KIRCHHEIMER, Otto. Punição e estrutura social. Tradução de Gizlene Neder. 2. ed. Rio de Janeiro: Revan, 2004.

SANTOS, Juarez Cirino dos. Prefácio à edição brasileira. In: MELOSSI, Dario; PAVARINI, Massimo. Cárcere e fábrica: as origens do sistema penitenciário (séculos XVI - XIX). Rio de Janeiro: Revan, 2006.

SHECAIRA, Sérgio Salomão. Criminologia. 6. ed. São Paulo: Revista dos Tribunais, 2014.

SILVA, José Adaumir Arruda da. A privatização de presídios: uma ressocialização perversa. Rio de Janeiro: Revan, 2016.

WACQUANT, Loïc. As prisões da miséria. Tradução de André Telles. Rio de Janeiro: Jorge Zahar, 2001.

. Punir os pobres: a nova gestão da miséria nos Estados Unidos. Tradução de Sérgio Lamarão. 3. ed. Rio de Janeiro: Revan, 2007. 